\title{
Pengaruh pH larutan elektrolit terhadap kuat lekat dan ketebalan hasil elektroplating bahan baja karbon rendah
}

\author{
Asroni $^{1}$, Sulis Dri Handono ${ }^{2}$, Tri Cahyo Wahyudi ${ }^{*}$, Yogi Saputra ${ }^{4}$ \\ 1,2,3 Jurusan Teknik Mesin, Fakultas Teknik, Universitas Muhammadiyah Metro \\ JI. Ki Hajar Dewantara 15 A Kota Metro, Lampung, Indonesia \\ ${ }^{4}$ Prodi Teknik Mesin, Fakultas Teknik, Universitas Muhammadiyah Metro \\ Jl. Ki Hajar Dewantara 15 A Kota Metro, Lampung, Indonesia \\ ${ }^{*}$ Corresponding author: tricahyowahyudi@ymail.com
}

\begin{abstract}
Electroplating is a process of coating a solid material with a metal layer using an electric current through an electrolyte solution. The purpose of this study was to obtain the best solution $\mathrm{pH}$ for the thickness and adhesive strength results of electroplating, as well as the method used in various electrolyte solutions, namely $\mathrm{pH} \mathrm{1.7,} \mathrm{pH} 3, \mathrm{pH} \mathrm{5,} \mathrm{pH} 7$ and $\mathrm{pH}$ 9. The anode was used Nickel while the cathode uses ST41 Steel with dimensions of $70 \mathrm{~mm} \times 50 \mathrm{~mm}$ $x 10 \mathrm{~mm}$. The distance between the anode and cathode is $10 \mathrm{~cm}$ and a DC current voltage of 5.5 volts with an immersion time of 20 minutes. The best coating were obtained at a variation of $\mathrm{pH} 1.7$ with a result of $0.0322 \mathrm{~mm}$ and adhesive strength at a variation of $\mathrm{pH} 5$ with a result of $26.53 \mathrm{MPa}$ and $\mathrm{pH} 7$ of $24.25 \mathrm{MPa}$.
\end{abstract}

Keywords: Electroplating, $p H$ variation, adhesion strength, thickness, Steel ST41, Nickel.

\begin{abstract}
Abstrak
Elektroplating merupakan salah satu proses pelapisan bahan padat dengan lapisan logam menggunakan arus listrik melalui suatu larutan elektrolit. Tujuan dari penelitian ini adalah untuk mendapatkan $\mathrm{pH}$ larutan terbaik terhadap hasil ketebalan dan kuat lekat hasil elektroplating, serta metode yang digunakan pada variasi larutan elektrolit yaitu $\mathrm{pH} 1.7, \mathrm{pH} 3$, $\mathrm{pH} 5, \mathrm{pH} 7$, dan $\mathrm{pH}$ 9. Anoda menggunakan logam Nikel sedangkan katoda menggunakan baja ST41 berdimensi $70 \mathrm{~mm}$ x $50 \mathrm{~mm}$ x $10 \mathrm{~mm}$. Jarak anoda dengan katoda $10 \mathrm{~cm}$ serta tegangan arus DC sebesar 5.5 Volt dengan waktu perendaman 20 menit, dari pengujian tersebut didapatkan hasil ketebalan lapisan terbaik pada variasi $\mathrm{pH} 1.7$ dengan hasil $0.0322 \mathrm{~mm}$ dan kekuatan lekat terdapat pada variasi $\mathrm{pH} 5$ dengan hasil $26.53 \mathrm{MPa}$ dan $\mathrm{pH} 7$ sebesar 24.25 MPa.
\end{abstract}

Kata kunci: Elektroplating, variasi pH, kekuatan lekat, ketebalan, Baja ST41, Nikel.

\section{Pendahuluan}

Elektroplating yaitu proses pelapisan logam dengan logam lain di dalam suatu larutan elektrolit dengan pembiasan arus listrik. Konsep yang digunakan dalam proses elektroplating adalah konsep reaksi reduksi dan oksidasi dengan menggunakan sel elektrolisa [1]. Anoda atau bahan pelapis adalah elektroda positif yang merupakan logam pelapis. Pada anoda terjadi oksidasi, ion bergerak (migrasi) ke anoda disebut anion [2].

Elektroplating juga dilakukan untuk mencapai sebuah finishing yang lebih baik sekaligus untuk mendapatkan nilai estetika yang menarik juga sebagai salah satu cara meminimalisir terjadinya korosi atau menghambat terjadinya proses oksidasi suatu material hingga material itu sendiri tetap utuh dan selalu tetap baik walaupun dalam penggunaanya di lapangan tidak memungkinkan material itu bisa bertahan dalam jangka waktu yang lama. Pada saat ini proses pelapisan yang dilakukan industri elektroplating dalam menghasilkan produknya yaitu dengan cara melapisi logam dengan material dasar yang berupa 
baja karbon rendah lalu dilapisi dengan Nikel atau krom [3].

Proses elektroplating mengubah sifat fisik, mekanik, dan sifat teknologi suatu material. Salah satu contoh perubahan fisik ketika material dilapis dengan Nikel adalah bertambahnya daya tahan material tersebut terhadap korosi, serta bertambahnya kapasitas konduktifitasnya. Adapun dalam sifat mekanik, terjadi perubahan kekuatan tarik maupun tekan dari suatu material sesudah mengalami pelapisan dibandingkan sebelumnya. Karena itu, tujuan pelapisan logam tidak luput dari tiga hal, yaitu untuk meningkatkan sifat teknis atau mekanis dari suatu logam, yang kedua melindungi logam dari korosi dimana logam sangat rentan terhadap laju korosi, dan ketiga memperindah tampilan [4].

Pelapisan Nikel menggunakan pada proses elektroplating ini selain menambah nilai estetika juga ketahanan terhadap korosi. Korosi adalah kerusakan atau degradasi logam yang disebabkan oleh berbagai zat yang ada di lingkungannya yang menghasilkan senyawa-senyawa yang tidak dikehendaki. Selain itu juga Nikel berguna sebagai bahan pelapis dasar untuk pelapisan krom, karena apabila baja ST41 secara langsung dilapisi oleh krom maka krom itu akan mudah terlepas apabila terjadi impak, dan tidak akan bertahan lama, maka dari itu pelapisan dasar Nikel sangat penting supaya baja ST41 kuat merekat dengan krom ketika terjadi impak krom tidak mudah pecah atau retak. Dengan adanya logam dasar Nikel maka pelapis krom akan mengikuti keelastisan Nikel karena Nikel dan krom nilai kekerasannya lebih keras krom dibandingkan Nikel [5].

\section{Tinjauan Pustaka}

Elektroplating berasal dari dua kata dasar yaitu elektro dan plating atau listrik dan pelapis yang mempunyai arti bahwa dalam suatu pelapisan yang disebut elektroplating adalah suatu pelapisan dimana pelapisan itu menggunakan listrik untuk melapisi logam antara bahan pelapis (anoda) dan yang akan dilapisi (katoda), dengan menggunakan arus listrik searah (DC). Pada prinsip kerjanya logam akan mengalami perubahan kimia secara fisik salah satu dari logam tersebut akan yang melepaskan ion-ion dan sebaliknya ada yang akan mengikat ion-ion yang terlepas akibat adanya energi listrik [6].

$$
\text { Prinsip dasar dari proses }
$$

elektroplating berdasarkan pada hukum Faraday yang menyatakan bahwa jumlah zat-zat yang terbentuk dan terbebas pada elektroda selama elektrolisis sebanding dengan jumlah arus listrik yang mengalir dalam larutan elektrolit. Di samping itu jumlah zat yang dihasilkan oleh arus listrik yang sama selama elektrolisis adalah sebanding dengan berat ekivalen masingmasing zat tersebut.

Faktor yang memepengaruhi elektroplating dalam operasi pelapisan, kondisi operasi perlu diperhatikan, karena kondisi tersebut akan menentukan berhasil atau tidaknya proses pelapisan serta mutu lapisan yang dihasilkan dan sebagai parameter-parameter yang berpengaruh terhadap kualitas pelapisan Nikel. Kondisi operasi yang perlu diperhatikan tersebut antara lain:

1. Rapat Arus (Current density). Rapat arus adalah bilangan yang menyatakan jumlah arus listrik yang mengalir per luas unit elektroda.

2. Tegangan (Voltage). Tegangan yang digunakan harus konstan sehingga yang divariabelkan hanyalah arusnya saja.

3. Temperatur (suhu larutan). Temperatur larutan dapat mempengaruhi hasil lapisan, kenaikan temperatur larutan menyebabkan bertambahnya ukuran Kristal pada temperatur tinggi.

4. $\mathrm{pH}$ larutan dipakai untuk menentukan derajat keasaman suatu larutan elektrolit dan dalam operasi lapis listrik, $\mathrm{pH}$ memiliki pengaruh tinggi terhadap larutan yang akan dideposisikan.

Baja karbon rendah merupakan material multiguna paling banyak 
digunakan, keunggulan dari baja karbon rendah yaitu pada sifat mekanik dan sifat fisiknya yang dapat ditingkatkan dengan proses penambahan unsur paduan dan perlakuan panas, namun memiliki kekurangan yaitu pada ketahanan terhadap korosi yang buruk, biasanya membutuhkan lapisan perlindungan atau pengkondisian lingkungan, baja karbon rendah (low carbon steel) mengandung karbon antara $0.025 \%$ $0.25 \%$ [7].

Selain mencegah korosi dan tahan panas, senyawa Nikel sering digunakan terutama sebagai katalis dalam elektroplating [8], karena Nikel merupakan unsur kimia yang terletak pada periode 4 golongan VIII-B, dengan nomor atom 28 dan massa atom 58,71. Nikel memiliki massa jenis $8,902 \mathrm{~g} / \mathrm{cm}^{3}$, titik lebur $1455^{\circ} \mathrm{C}$, dan titik didih $2827^{\circ} \mathrm{C}$. Struktur kristal Nikel adalah FCC (face centered cubic) dengan parameter lattice $\mathrm{a}=0.35243 \mathrm{~nm}$ (pada $25^{\circ} \mathrm{C}$ ), jari-jari atom $0.1246 \mathrm{~nm}$, dan elektronegativitas 1,8 .

Sebagai logam, Nikel memiliki kekuatan dan kekerasan sedang, serta keliatan dan keuletan baik [9]. Proses pelapisan pada Nikel berpengaruh terhadap hasil kekuatan pada materialnya [10].

\section{Metode Penelitian}

Pada penelitian ini dilakukan pengujian ketebalan serta pengujian kerekatan pada proses elektroplating yang dilakukan di Laboratorium Teknik Mesin Universitas Muhammadiyah Metro dari bulan September 2020 sampai dengan Desember 2020.

Bahan yang digunakan Asam Sulfat sebanyak $225 \mathrm{ml}$ dan $3 \mathrm{~kg}$ Nikel Sulfat, aquades 15 liter, bahan anoda yang digunakan adalah Nikel dan katoda menggunakan baja ST41 yang berdimensi $70 \mathrm{~mm}$ x $25 \mathrm{~mm}$ x $20 \mathrm{~mm}$. Untuk jarak anoda dan katoda sejauh $10 \mathrm{~cm}$, waktu pencelupan 20 menit serta variasi larutan elektrolit pada penelitian menggunakan pH1.7, pH 3, pH 5, pH 7 dan pH 9.

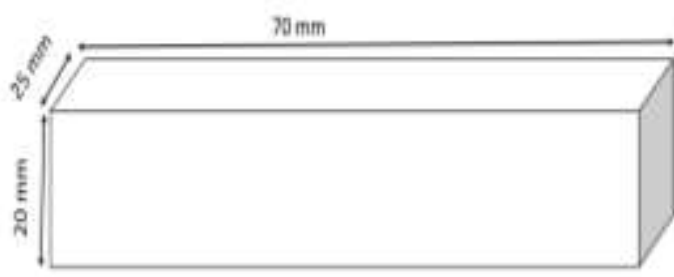

Gambar1. Spesimen elektroplating

\section{Persiapan penelitian}

a. Mempersiapkan bahan, dalam hal ini pelat baja karbon rendah (katoda).

b. Mempersiapkan larutan elektrolit asam sulfat $\left(\mathrm{H}_{2} \mathrm{SO}_{4}\right)$.

c. Pembuatan spesimen, memotong pelat baja dengan dimensi $70 \mathrm{~mm} \times 25 \mathrm{~mm} \mathrm{x}$ $20 \mathrm{~mm}$.

d. Membersihkan dan menghaluskan permukaan spesimen menggunakan gerinda.

e. Mengukur ketebalan spesimen untuk mengetahui perbandingan setelah pengujian.

f. Merendam spesimen dengan menggunakan larutan alkali selama 5 menit.

g. Keringkan spesimen dengan suhu ruangan.

h. Menghubungkan spesimen pada arus listrik negatif.

i. Menghubungkan logam Nikel pada arus listrik positif.

Setelah benda kerja betul-betul bebas dari pengotor, maka benda kerja tersebut sudah siap untuk dilapisi. Rangkaian sistem pelapisan dapat dilihat seperti yang digambarkan pada gambar berikut:

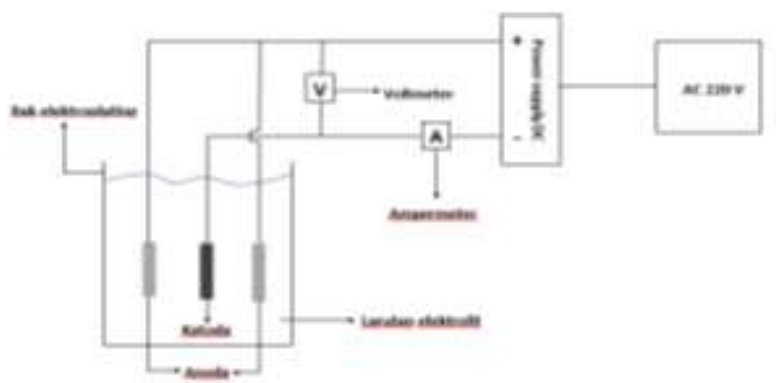

Gambar 2. Skematis rangkaian pelapisan listrik.

\section{Proses pelapisan (elektroplating)}

1. Mencelupkan logam Nikel ke dalam bak larutan. 
2. Mengatur tegangan (V) yang telah ditentukan nilainya.

3. Mencelupkan spesimen ke dalam bak larutan dengan jarak $10 \mathrm{~cm}$

4. Menghidupkan stopwatch bersamaan dengan mencelupkan spesimen kedalam bak larutan.

5. Mengangkat spesimen pada waktu yang telah ditentukan.

6. Membersihkan spesimen dengan menggunakan air.

7. Lakukan pengujian ketebalan dan kerekatan pada spesimen.

\section{Pengukuran tebal lapisan}

Adapun langkah-langkah pengukuran tebal lapisan adalah sebagai berikut:

1. Mengukur ketebalan sebelum dan sesudah proses elektroplating dilakukan, bahan uji dari masingmasing.

2. Setelah mendapatkan ukuran, kemudian dilakukan perhitungan perbandingan antara sebelum dan sesudah proses elektroplating maka akan didapat nilai ketebalan pada lapisan dari proses elektroplating.

3. Mencatat hasi-hasill pengukuran yang telah dilakukan baik sebelum maupun sesudah proses pelapisan berlangsung.

4. Mengukur beberapa bahan uji dengan metode yang sama.

\section{Pengujian kelekatan lapisan}

Adapun langkah-langkah pengukuran kelekatan lapisan adalah sebagai berikut:

1. Pengait ditempelkan pada spesimen menggunakan lem lalu dibiarkan mengering.

2. Bersihkan spesimen dari sisa-sisa lem pada samping alat penarik dengan menggunakan alat cutting tool yang berbentuk bulat.

3. Melakukan pengujian pull-off dengan memasukan tuas penarik ke dalam alat penarik yang terhubung dengan alat pembaca tekanan. Kemudian mulai proses penarikan sampai lapisan coating terkelupas.

4. Mencatat hasil pengujian yang telah dilakukan.
5. Menguji spesimen lain dengan metode yang sama.

\section{Hasil dan Pembahasan}

Hasil data penelitian pengaruh $\mathbf{p H}$ larutan elektrolit terhadap kuat lekat pada proses elektroplating

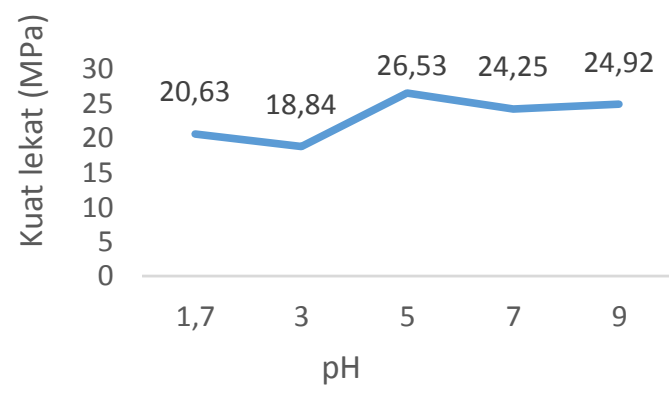

Gambar 3. Grafik Kuat Lekat (MPa)

Dengan hasil nilai rata-rata yang didapat pada spesimen dengan ph 1.7 mendapatkan nilai 20.63 MPa serta lapisan dapat terangkat pada pengujian ke 2 . Penurunan grafik terjadi pada spesimen dengan pH 3 yang mendapat nilai 18.84 MPa serta mengalami pengangatan lapisan pada pengujian ke-1 dan ke-2, sehingga pada penelitian ini larutan elektrolit dengan pH 3 dirasa kurang baik, pada spesimen dengan $\mathrm{pH} 5$ mendapatkan nilai yang sangat baik dan mengalami kenaikan grafik yang cukup tinggi dengan nilai $26.53 \mathrm{MPa}$ dan tidak mengalami pengangkatan lapisan pada saat dilakukan pengujian sehingga larutan dengan pH 5 mendapatkan nilai terbaik pada penelitian ini.

Pada spesimen 4 dengan $\mathrm{pH} \quad 7$ mengalami sedikit penurunan dengan nilai sebesar $24.25 \mathrm{MPa}$ serta tidak mengalami pengelupasan lapisan saat dilakukan pengujian, pada spesimen 5 dengan $\mathrm{pH} 9$ mengalami kenaikan grafik yang sedikit dengan mendapatkan nilai kuat lekat sebesar 24.92 $\mathrm{MPa}$ namun pada saat dilakukan pengujian mengalami pengangkatan lapisan Nikel pada pengujian 1, 2, dan 3 dikarenakan lapisan pada $\mathrm{pH} 9$ sangat tipis dan kurang merata sehingga lapisan mudah terangkat.

Pada penelitian ini didapatkan $\mathrm{pH}$ terbaik yaitu $\mathrm{pH} 5$ dan $\mathrm{pH} 7$ yang tidak 
megalami pengangkatan lapisan saat dilakukan 3 kali pengujian. Sehingga pada pengujian ini dapat dinyatakan bahwa $\mathrm{pH}$ terlalu tinggi kurang baik terhadap kekuatan lekat dan sebalikya $\mathrm{pH}$ terlalu rendah atau asam juga kurang baik karena larutan yang terlalu asam mengakibatkan semakin banyak pula ion-ion pelapis yang didistribusikan ke katoda dan lapisan deposisi menjadi semakin tebal, karena pada lapisan yang terlalu tebal cenderung mudah retak dan memiliki kekuatan lekat kurang baik.

\section{Hasil pengaruh pH larutan elektrolit terhadap ketebalan pada proses elektroplating}

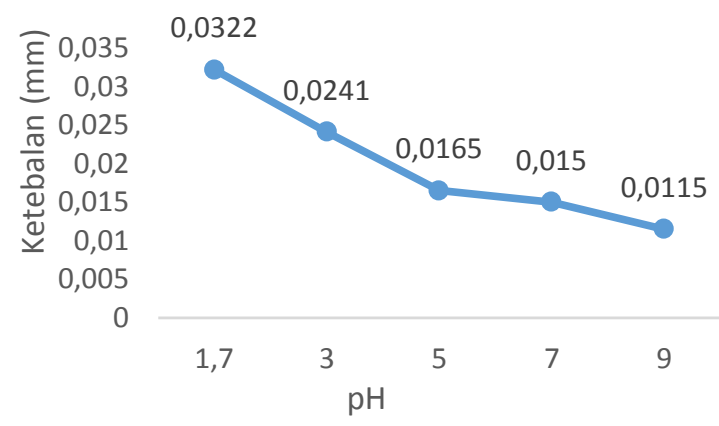

Gambar 4. Grafik Ketebalan (mm)

Pada pengujian pengaruh $\mathrm{pH}$ larutan terhadap hasil ketebalan didapatkan hasil bahwa semakin asam larutan elektrolit maka nilai ketebalan semakin tinggi. Pada spesimen dengan $\mathrm{pH}$ 1,3 mendapat nilai ketebalan paling tinggi dengan nilai 0.0322 $\mathrm{mm}$, pada spesimen dengan $\mathrm{pH} 3$ mengalami penurunan dengan nilai $0.0241 \mathrm{~mm}$, dan spesimen dengan $\mathrm{pH} 5$, yang terus mengalami penurunan sampai dengan $\mathrm{pH}$, pada grafik sangat terlihat bahwa semakin tinggi $\mathrm{pH}$ grafik mengalami penurunan seiring dengan bertambahnya $\mathrm{pH}$ larutan elektrolit. Pada pengujian ketebalan didapat nilai ketebalan terbaik pada spesimen dengan pH 1.7 dengan nilai ketebalan 0.0322 dan nilai ketebalan paling rendah didapat pada spesimen 5 dengan $\mathrm{pH} 9$ yang hanya mendapat nilai ketebalan sebesar $0.0115 \mathrm{~mm}$.

Pada hasil pengujian ketebalan ini menhasilkan Semakin asam larutan elektrolit, maka konsentrasi ion hidrogennya semakin tinggi dan aliran arus dari anoda ke katoda semakin besar, mengakibatkan semakin banyak pula ion-ion pelapis yang dipindahkan ke katoda dan lapisan deposisi menjadi semakin tebal [11][12].

\section{Kesimpulan}

Ketebalan lapisan terbaik dari penelitian elektroplating terdapat pada variasi $\mathrm{pH} 1.7$ dengan hasil yang diperoleh sebesar $0.0322 \mathrm{~mm}$. Tetapi terlalu tebal lapisan juga kurang baik terhadap nilai kuat lekat. Kekuatan lekat terbaik dari penelitian elektroplating terdapat pada variasi $\mathrm{pH} 5$ dengan hasil yang diperoleh sebesar 26.53 MPa dan pH 7 dengan hasil yang diperoleh sebesar $24.25 \mathrm{MPa}$, karena pada saat pengujian dua sepesimen tersebut tidak mengalami pengangkatan lapisan pada lapisan spesimen saat dilakukan 3 kali pengujian. Jadi $\mathrm{pH}$ larutan elektrolit terbaik pada penelitian ini antara $\mathrm{pH} 5$ sampai dengan $\mathrm{pH} 7$.

\section{Referensi}

[1] Asroni, A., Rajabiah, N., \& Fahlevi, D. (2020). Pengaruh waktu celup dan tegangan listrik terhadap hasil elektroplating bahan baja karbon rendah. Turbo: Jurnal Program Studi Teknik Mesin, 9(2).

[2] Basmal, dkk, (2012), "Pengaruh Variasi Suhu dan Waktu Pelapisan Tembaga - Nikel Pada Baja Karbon Rendah Secara Elektroplating Terhadap Nilai Ketebalan dan Nilai Kekasaran“ Jurnal Tesis Universitas Diponegoro, Semarang.

[3] Permadi, B., Asroni, A., \& Budiyanto, E. (2020). Proses elektroplating nikel dengan variasi jarak anoda katoda dan tegangan listrik pada baja ST41. Turbo: Jurnal Program Studi Teknik Mesin, 8(2).

[4] PT. Graha Jaya Pratama Kinerja, (2017), "pengertian-electroplating" (Online),(http://blog.grahachemical.c o.id/pengertian electroplating, Diakses Tanggal 03 Februari 2020). 
[5] Tamprin, Mohammad 2013, "Studi Pelapisan Krom Dengan Proses Elektroplating Pada Handel Rem Sepeda Motor Dengan Variasi Rapat Arus", Naskah Publikasi, Universitas Muhammadiyah Surakarta.

[6] Cahyono, Darmalia dan Tjahjanti, (2016), "Analisa Produk Elektroplating As Sepeda Motor Dari Home Industri Di Pasuruan", SenasPro 17-18 Oktober 2016, Universitas Muhammadiyah Malang.

[7] Aziz Abdul, (2015), "Pengaruh pH Dan Tegangan Listrik Dalam Elektrolisis Limbah Padat Baja (Slag Eaf) Sebagai Upaya Mereduksi Kandungan Logam Fe Pada Limbah Padat Industri Galvanis", Tugas Akhir Program studi Pendidikan Kimia Universitas Islam Negeri Walisongo Semarang.

[8] Mulyadi Agung Tris, (2018), "Pengaruh Variasi Waktu Elektroplating Tembaga, Nikel Dan Tembaga - Nikel - Ferro Terhadap Laju Korosi Pada Baja Karbon Rendah", Tugas Akhir, Teknik Mesin Universitas Negri Jakarta.

[9] Andinata Febryan dkk, (2012), "Pengaruh pH Larutan Elektrolit Terhadap Tebal Lapisan Elektroplating Nikel Pada Baja St 37”, Jurnal Penelitian Fisika Dan Aplikasinya, Jurusan Fisika FMIPA Universitas Negeri Surabaya.

[10] P Jauhari M, Mahendra Sakti Arya, (2019), "Pengaruh Variasi Tegangan dan Waktu pada Proses Pelapisan Nikel terhadap Kekuatan Bending Baja ST 41", Jurusan Teknik Mesin, Fakultas Teknik, Universitas Negeri Surabaya.

[11] Saleh A.A, (2014), “ Teknik Pelapisan Logam dengan Cara Listrik “, Yrama Widya, Bandung.

[12] Budiyanto, E., Setiawan, D. A., Supriadi, H., \& Ridhuan, K. (2017). Pengaruh jarak anoda-katoda pada proses elektroplating tembaga terhadap ketebalan lapisan dan efisiensi katoda baja AISI 1020. Turbo: Jurnal Program Studi Teknik Mesin, 5(1). 